\title{
The correlation of EQ and work motivation with elementary schools teachers' engagement in decision- making
}

\author{
Novianty Djafri ${ }^{1}$, Kadim Masaong ${ }^{2}$, Murtia Dai $^{3}$ \\ \{novianty@gmail.com ${ }^{1}$ \} \\ ${ }^{1,2,3}$ Department of Education Management, Faculty of Education, Universitas Negeri Gorontalo, \\ Gorontalo, Indonesia
}

\begin{abstract}
The objective of this research is to investigate the correlation between some aspects in decision-making process, namely: (1) the correlation between emotional intelligence (henceforth referred to as EQ) and teachers' engagement; (2) the correlation between work motivation and teachers' engagement, and; (3) the correlation between EQ and work motivation (simultaneous) with teachers' engagement in decision-making. Conducted in all elementary schools in Kota Selatan Sub-district, this correlational study relied on observation, interview, documentation, and quantitative data analysis. Key findings of the study reveal that (1) there is a positive and significant correlation between EQ and teachers' engagement; (2) there is a positive and significant correlation between work motivation and teachers' engagement, and (3) there is a positive, significant, and simultaneous correlation of EQ and work motivation with teachers' engagement.
\end{abstract}

Keywords: Emotional intelligence, work motivation, decision-making

\section{Introduction}

Teachers are the main actor other than parents and related elements that contribute to the success of education. Every teacher is responsible for his or her students.

Emotional intelligence or emotional quotient (henceforth referred to as EQ) encompasses some skills, e.g. self-control, enthusiasm and perseverance, self-motivation and empathy to other people. High EQ is, therefore, crucial for teachers, especially those who teach at elementary schools. The preliminary observation at elementary school SDN 33 Kota Selatan shows some problems regarding teachers' EQ. According to the school principal, the percentage of teachers' attendance in school programs (such as meetings to discuss curriculum, lesson plan and syllabus development, school budget, student admission and graduation, as well as designing textbook) only reaches $88.94 \%$. This finding implies the absence of some teachers during the meeting. Furthermore, such information indicates different participation among the teachers. The level of teachers' participation in school meetings, based on the analysis of attendance list, ranges from $75 \%-100 \%$.

EQ is simply defined as the ability to read, write and calculate; this literacy and numeracy skill has been the focus of formal education (at schools). EQ refers to one's ability to express his or her feeling and to understand feeling and gain control of it. Besides, EQ correlates with awareness. This intelligence also involves self-motivation skills which are helpful to cope with frustration, to control feeling (such as happiness) and to manage stress as it can distract 
thinking capacity (Goleman, 2004, p.45). Mayer and Salovey (as cited in Mubayidh, 2006) further add that EQ, as a part of social intelligence, correlates with the way a person monitors self-emotion and comprehend emotion of others (p.15). This skill enables the individuals to distinguish their emotion from other people's feeling; as a result, the person can direct his or her mindset and behavior.

From the above definition, this paper concludes that EQ is about accepting, managing, motivating, and gaining control of oneself and other elements surrounding the individuals, such as other people's feeling and emotion.

Purwanto (2003) explains motivation as a complex entity in an organization functioning to direct organization goals and stimulate the member of the organization to achieve it (p.61). Moreover, Dimyati (2010) points out that motivation is a goal-oriented driving force (p.81).

Similarly, Siagian (2008) argues that motivation functions to nurture the willingness of the members of an organization to perform all out and develop self-capacity and skills as a part of their responsibility to attain the organizational objective (p.138).

Decision-making process is a conscious process to find one among various alternatives to solve a problem (Siagian, 1993, p.24). One must take into account the current problems of the organization in deciding efficient solutions among other available choices (Salusu, 1996, p.47). Handoko (2001) shares a similar perspective on defining decision-making process; he asserts that a series of activities are attempted to deal with particular issues (p.129).

The process undergone to determine the efforts to deal with difficult situations is among the key concept of decision-making (Stoner, as cited in Azjar, 2010, p.35). Furthermore, Terry (2012) claims that effective solutions from the decision-making process contribute to the outcomes of future activities (p.55).

The above background urges a study to examine the correlation between (1) EQ and teachers' engagement; (2) work motivation and teachers' engagement, and; (3) the simultaneous correlation of EQ and work motivation with teachers' engagement in the decision-making process in all elementary schools in Kota Selatan Sub-district.

\section{Method}

Employing a quantitative approach, this correlational study focused on examining three variables, including 1) teachers' EQ, 2) teachers' work motivation, and 3) teachers' participation in decision-making.

The population of this study involved elementary school teachers from all schools in Kota Selatan Sub-district, Gorontalo. Among all 127 teachers as the population, only 96 of which were selected as the sample using a formula by Isaac and Michael (as cited in Sugiyono).

The data were collected from survey, interview, observation, and documentation. Likert scale was used in the survey comprising closed-ended questions; the responses of the survey consisted of always, often, rarely, seldom, and never.

A validity test was employed to address the problem statement of the research. The test was also to examine the data from the respondents and the reliability of the research instrument. In addition, the study also assessed the normality of the dependent variable (Ghozali, 2001,p.86).

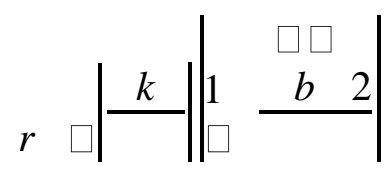




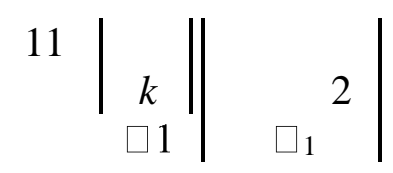

The hypothesis was examined using a partial correlation coefficient test (t-test); the formula is as follows:

$t=$

A simultaneous regression coefficient test (f-test) was also utilized in the research; the F value was calculated using the following formula:

$F \quad=$

In conclusion, the above tests, i.e. t-statistics and F-statistics, were opted to examine the research hypothesis.

\section{Results and Discussion}

\section{Descriptive Statistics Analysis}

a. The Results of Descriptive Statistics Analysis of X1 Variable

The results of the descriptive statistics analysis of X1 variable (EQ) of 96 respondents reveal that the maximum score arrives at 113 with the minimum score 62 . Moreover, the result has identified eight class intervals with its width measuring at seven. (The analysis result of the survey is provided in Appendix 4).

The distribution of the frequency of $\mathrm{X} 1$ variable is seen in the following chart.

20

18

16

14

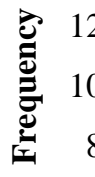

4

2
19

18

16

14

11

Figure 1.

\section{Class Interval}


According to the above chart, the mode of $\mathrm{X} 1$ variable is 87.25 , and the median is 89.5 ; the average and the standard deviation get 89.94 and 12.56 respectively.

\section{b. The Results of Descriptive Statistics Analysis of X2 Variable}

The analysis of X2 variable (work motivation) shows that the maximum score arrives at 99 with the minimum score 54. Moreover, the result has identified eight class interval with its width measuring at six. The distribution of the frequency of $\mathrm{X} 2$ variable is seen in the following chart.

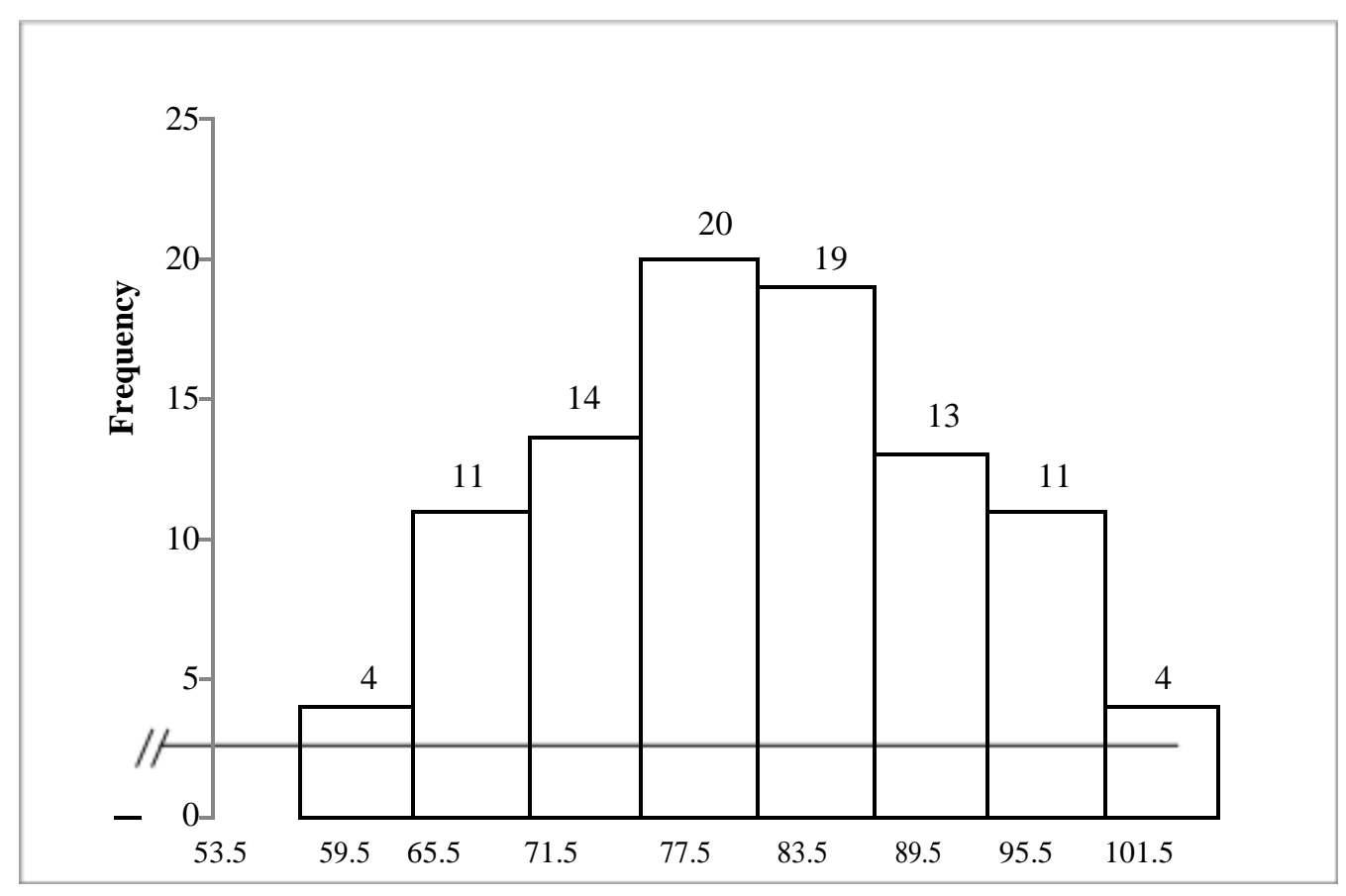

Class Interval

Figure 2.

Based on the above figure, the mode of X2 variable is 76.64, and the median is 77.2 ; the average and the standard deviation gets 77.38 and 10.77 respectively.

c. The Results of Descriptive Statistics Analysis of Y Variable

The analysis of Y variable (teachers' engagement in the decision-making process) shows that the maximum score arrives at 116 with the minimum score 64 . Moreover, the result has identified eight class interval with its width measuring at seven. The distribution of the frequency of $\mathrm{Y}$ variable is seen in the following figure. 


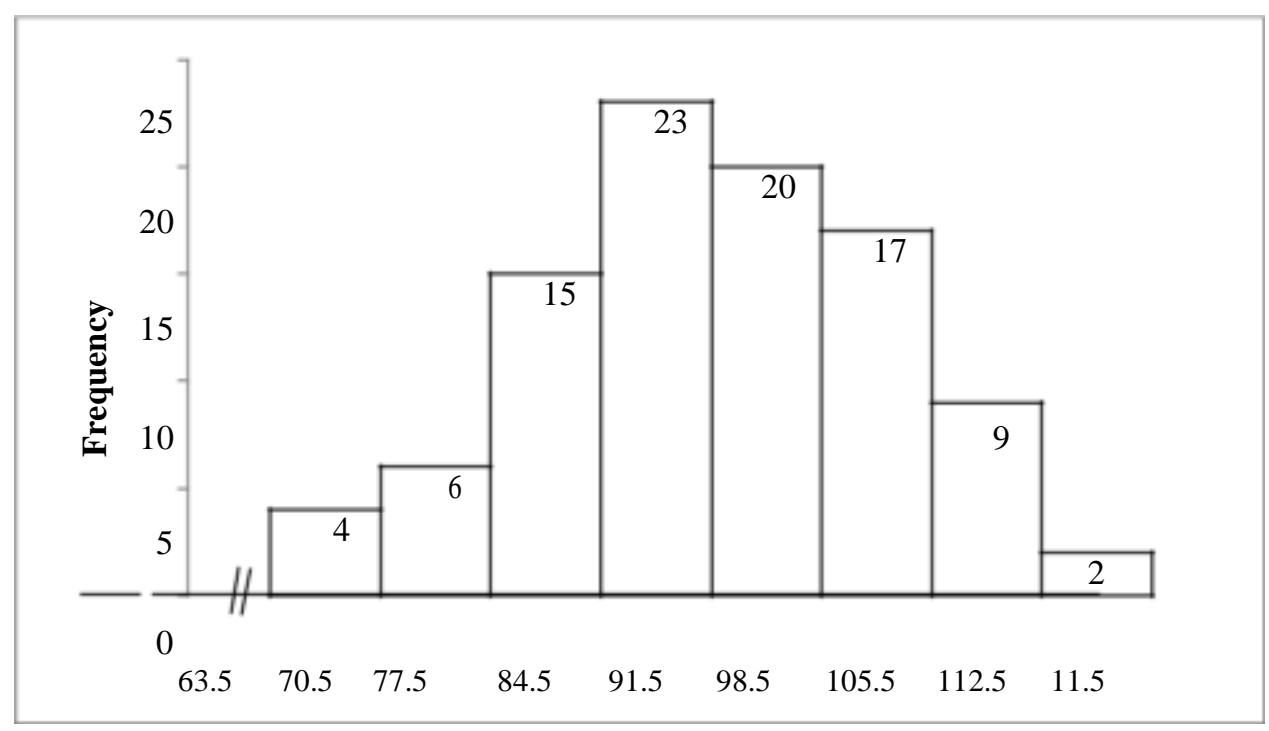

Class Interval

Figure 3.

From the above histogram, the mode of $\mathrm{Y}$ variable is 89.59 , and the median is 91.5 ; the average and the standard deviation gets 91.15 and 11.35 respectively.

\section{Basic Assumption Test Results}

The assumption test was performed by analyzing the normality of the research data. It was aimed at examining the normality of every research variable; the test is the requirement before proceeding to the hypothesis testing as the data selected should be good regression model. Data with good regression model are well-known for its normal distribution. The normality test was performed using a statistical test Chi-square. Further detail of the data normality test is seen in Appendix 5. In short, the results of the analysis are explained in the following sections.

\section{a. Results of Normality Test of EQ (X1) Variable}

The value of EQ (X1) variable, according to the result of the normality analysis, reaches the count $=2.49$ with the value of table at the significance level $\alpha=0.05$ gets (0.95) (5) $=$ 11.1. The results reveal the value of count $=2.49<$ table $=11.1$. Such outcomes signify that the data distribution of the EQ variable is normally distributed; this also implies that the normality of the data of $\mathrm{X} 1$ variable meets the requirement to proceed to the hypothesis testing. 


\section{b. Results of Normality Test of Work Motivation (X2) Variable}

The value of work motivation (X2) variable, according to the result of the normality analysis, the table is 2.67. In addition, the value of table with the significance level $\alpha=0.05$ gets 11.1 - this is from the calculation of (0.95) (5), meaning that the value of count $=2.49<$ table $=11.1$. The result also brings out the fact that the work motivation variable is normally distributed, and ultimately, the normality of the data of X2 variable meets the requirement to proceed to the hypothesis testing.

\section{c. Results of Normality Test of Teachers' Participation in Decision-making (Y) Variable}

The value of teachers' participation in decision-making (Y) variable, based on the result of the normality analysis, gets count $=2.3$. Furthermore, the value of table at the significance level $\alpha=0.05$, gets $\quad(0.95)(5)=11.1$. The result of the analysis shows that , signifying that the value count $=2.3<$ table $=11.1$. Such outcomes signify data distribution of the quality of school administration service is normally distributed. Thereby, the normality of the data of $\mathrm{Y}$ variable meets the requirement to proceed to the hypothesis testing.

\section{Results of Correlational Analysis (R)}

The correlational value ranges from 0 to 1 ; if the value is close to 1 , the correlation will be more significant. On the other hand, if the value is close to 0 , the correlation will be less significant. Guidelines in interpreting the correlational coefficient is seen in Table 3.8; the guidelines used in this study adopt the model by Sugiyono (2007), which is aimed at examining the strength of the correlational relationship.

\section{a.Multiple Correlational Analysis (R) and Determinant Analysis (R2)}

Grounding from the research problem statement, the purpose of correlational analysis is to find out the correlation between X1 (EQ) variable and Y (teachers' participation in decisionmaking), the correlation between X2 (work motivation) variable and Y (teachers' participation in decision-making) variable, and the correlation between independent variables (X1 and X2) with dependent variable (Y) simultaneously, and the direction of each correlation. Pearson product-moment formula was used to determine the correlation; the formula is as follows:

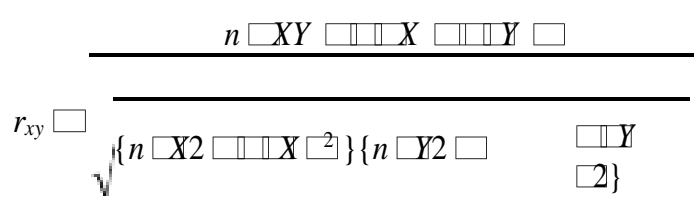

Furthermore, the determinant analysis in multiple linear analysis was used to determine the percentage of the independent variables in strengthening its correlation with the dependent variable (Y). 
1)The correlational analysis between $X 1$ variable with $Y$ variable

$$
\begin{array}{ll}
= & 0.804 \\
= & 0.8042=0.646
\end{array}
$$

The correlational value (R), according to the result of data analysis, reaches 0.804 . According to Table 3.8, such an outcome falls under very strong correlation category, meaning that X1 variable (EQ) significantly correlates with Y variable (teachers' participation in decision-making). The value of determinant coefficient (R2), based on the result of data analysis, gets 0.646 or $64.6 \%$. Such outcomes imply that the percentage of X1 variable in strengthening its correlation with $\mathrm{Y}$ variable is $64.6 \%$; on the other hand, the remaining $35.4 \%$ refers to other variables excluded from this study.

2) Correlational Analysis between $X 2$ variable with $Y$ variable

$\mathrm{Y}=0.913(0.9132=0.834)$

The correlational value (R), according to the result of data analysis, reaches 0.913 . As seen in Table 3.8, such an outcome is categorized very strong correlation, meaning that $\mathrm{X} 2$ variable (work motivation) significantly correlates with Y variable (teachers' participation in decisionmaking). The value of determinant coefficient (R2), based on the result of data analysis, gets 0.834 or $83.4 \%$. Such outcomes imply that the percentage of $\mathrm{X} 2$ variable in strengthening its correlation with $\mathrm{Y}$ variable is $64.6 \%$; on the other hand, the remaining $35.4 \%$ refers to other variables excluded from this study.

3) The correlational analysis between $\mathrm{X} 1$ and $\mathrm{X} 2$ variable with $\mathrm{Y}$ variable

The correlational analysis with two independent variables can be determined using the following formula.

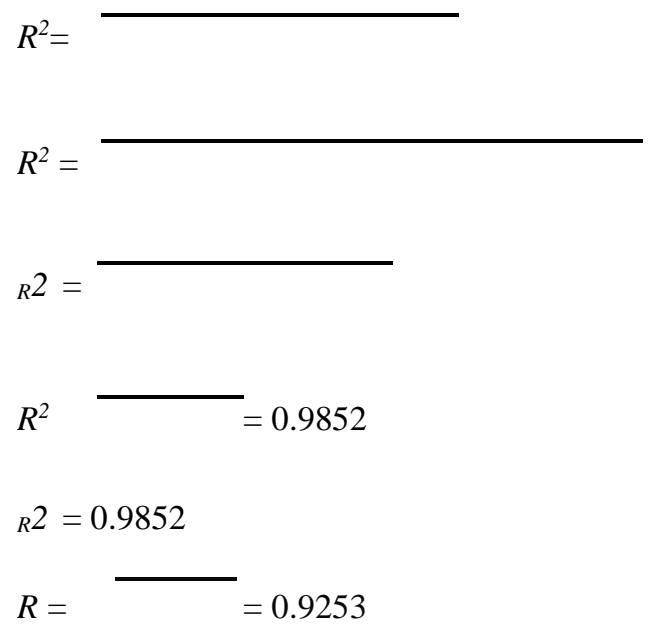


The correlational value (R), according to the result of data analysis, gets 0.9253 . According to Table 3.8, such an outcome is categorized very strong correlation, meaning that $\mathrm{X}$ (teachers' $\mathrm{EQ}$ and work motivation) variable significantly correlates with $\mathrm{Y}$ variable (teachers' participation in decision-making). The value of determinant coefficient (R2), based on the result of data analysis, achieves 0.8562 or $85.62 \%$. Such an outcome indicates that the percentage of the independent variables $(\mathrm{X})$ in strengthening its correlation with dependent variable (Y) reaches $85.62 \%$. The percentage represents the capability of $\mathrm{X}$ variable in strengthening its correlation with Y variable; on the other hand, the remaining $14.38 \%$ refers to other variables excluded from this study.

\section{Statistical Hypothesis Testing \\ a. Partial Regression Coefficient Analysis (t-test)}

A partial regression coefficient $t$ test was employed to find out whether or not the regression model of the independent variables (X1 and X2) partially or individually correlate with the dependent variable ( $Y$ variable). In the current study, the correlation variables of EQ and work motivation of the teachers with the decision-making process were examined individually using the statistics test mentioned earlier.

The result describing the contribution of the above variables on the decision-making process of teachers in all elementary schools in Kota Selatan Sub-district, Gorontalo concludes is shown in the following chart.

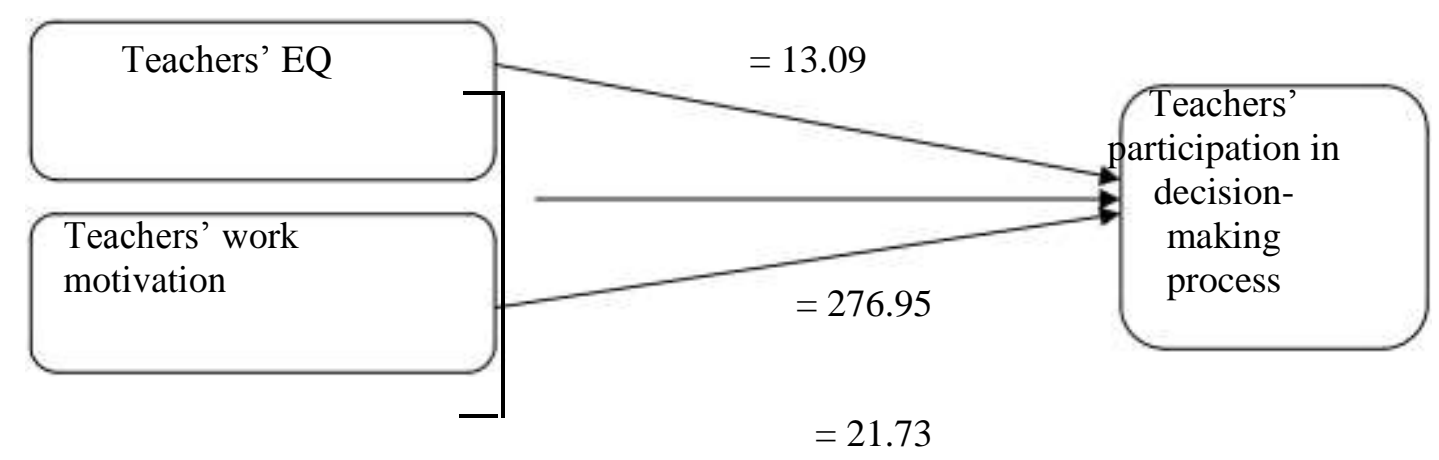

\section{The Correlation of EQ with Teachers' Engagement}

This research finds that the EQ and participation of teachers in decision-making decision are significantly correlated. According to the regression equation, the coefficient regression of the variable of EQ (X1) reaches 0.913 . The value implies that an increase by 1 point in EQ will be followed by an increase of 0.719 in $\mathrm{Y}$ variable. Positive correlation between $\mathrm{X} 1$ variable and $\mathrm{Y}$ variable is represented by positive regression coefficient of EQ variable. On the other hand, a decline in the EQ variable also leads to a drop in the value of teachers' participation in decision-making. The above discussion emphasizes a positive and significant correlation of EQ with teachers' engagement. 
2. The Correlation between Teachers' Work Motivation and Teachers' Engagement in Decision-making

This research finds that the EQ and participation of teachers in decision-making decision are significantly correlated. The regression coefficient of X2 variable or teachers' work motivation is 0.998 . In other words, an increase by 1 point in the variable of work motivation will be followed by an increase of 0.998 in $\mathrm{Y}$ variable, meaning that the two variables are correlated and influenced each other.

The above discussion emphasizes a positive and significant correlation of teachers' work motivation with teachers' engagement in the process of decision-making.

3. The Simultaneous Correlation of EQ and Teachers' Work Motivation with Teachers' Engagement in Decision-making

The correlational value $(\mathrm{R})$, according to the result of data analysis, reaches 0.9253 . According to Table 3.8, such an outcome is categorized very strong correlation, meaning that $\mathrm{X}$ (teachers' EQ and work motivation) variables significantly correlate with $\mathrm{Y}$ variable (teachers' participation in decision-making). The simultaneous statistic test, i.e. F test also emphasizes the way $\mathrm{X}$ variables (X1 and $\mathrm{X} 2$ ) highly correlate with $\mathrm{Y}$ variable. This study has identified that EQ and work motivation has a significant correlation (simultaneously) with the teachers' engagement in decision-making in all elementary schools in Kota Selatan Subdistrict.

Both EQ and work motivation are central to supporting teachers in their activities, such as during the decision-making process.

\section{Conclusion}

The current study focuses on examining the contribution of selected aspects on the decision-making process of teachers in all elementary schools in Kota Selatan Sub-district, Gorontalo. It concludes that: 1) there is a positive and significant correlation between EQ and teachers' engagement; there is a positive and significant correlation between work motivation and teachers' engagement, and (3) there is a positive and significant correlation of EQ and work motivation (simultaneously) with teachers' engagement.

\section{References}

Arikunto, S.(2010). Prosedurpenelitian:Suatupendekatanpraktek. Jakarta:RinekaCipta.

Azhar, K. (2010). Teoripemberiankeputusan. Jakarta: Penerbit FE.UI.

Cooper, R. K.,\&Ayman, S. (2002). Kecerdasanemosionalkepemimpinandariorganisasi. Jakarta: GramediaPustakaUtama.

Danang, S. (2012). Manajemensumberdayamanusia. Jakarta: PT BukuSeru.

Davis, K., \&Newstrom. (200). Perilakudalamorganisasi (vol. 1). Jakarta: Erlangga.

Depdiknas. (2008). MPMBS, Panduanmonitoring danevaluasi. Jakarta: DepartemenPendidikanNasional.

Djatmiko, Y. H. (2002). Perilakuorganisasi. Bandung: CV Alfabeta.

Fahmi, A. (2014). Proses decision making denganmelibatkanstakeholderssekolah. JurnalPedagogy, 1(2),1-8. 
Fatimah, S. (2017). Peranguru agama dalammengembangkankecerdasanemosionaldan spiritual padaanak di SMP Swasta Al-Hikmah Medan MarelanPasar IV Barat. Medan: FakultasIlmuTarbiyahdanKeguruanUniversitas Islam Negeri Sumatera Utara.

Gardner, H. (2003). KecerdasanMajemuk. Batam: Interaksara.

Ghozali, I. (2005). Aplikasianalisis multivariate dengan program SPSS ( $\left.3^{\text {rd }} \mathrm{ed}\right)$. Semarang: BadanPenerbitUniversitasDiponegoro.

Goleman, D.(2003). Kepemimpinanyang mendatangkanhasil( $\left.1^{\text {st }} \mathrm{ed}\right)$. Jogjakarta: Amara Books.

Gouzali, S. (2000). Manajemensumberdayamanusia (human resource), suatupendekatanmikro. Jakarta: Djambatan.

Gibson, J. L., John, M. I., \& James, H. D. (2010). Organisasi: Perilaku, strukturdan proses. Jakarta: BinarupaAksara.

Handoko, H. (2001). Manajemen (2 $\left.2^{\text {nd }} e d\right)$. Yogyakarta: BPFE.

Harianja, M. T. E. (2009). Manajemensumberdayamanusia. Jakarta: PT GramediaWidiasarana.

Hasan, M. I. (2002). Pokok-pokokpengambilankeputusan. Jakarta: Ghalia Indonesia.

Hasibuan, M. S.P. (2008). Manajemensumberdayamanusia. Jakarta: PenerbitBumiAksara.

Kurniawan, $\quad$ B.,\&Zulkaida, $\quad$ A. (2013) KontribusikecerdasanemosionalterhadapkemandirianmahasiswaPerguruanTinggiKedi nasan X. Jurnal Proceeding PESAT (Psikologi, Ekonomi, Sastra, Arsitektur\&TeknikSipil),5,53-60.

Mangkunegara, A.A., \&Prabu, A. (2009). Evaluasikinerjasumberdayamanusia. Bandung: RefikaAditama.

Martin, A. D. (2003). Emotional quality management: Refleksi, revisidanrevitalisasihidupmelaluikekuatanemosi. Jakarta: PenerbitArga.

Masaong, A. K. (2012). Hubungankecerdasanemosionaldankecerdasan spiritual dengangayakepemimpinankepalasekolahpadaSekolahMenengahKejuruanNegeri di Kota Gorontalo. UniversitasNegeriGorontalo.

Masaong, A. K., \&Tilome, A. (2011). Kepemimpinanberbasis multiple intelegence. (Sinergikecerdasanintelektual, emosional, danspritualuntukmeraihkesuksesan yang gemilang). Bandung: Alfabeta.

Mubayidh, M. (2006). Kecerdasandankesehatanemosionalanak: Referensipentingbagi para pendidikdan orang tua. Jakarta: Pustaka Al-Kautsar.

Notoatmodjo, S. (2009). Pengembangansumberdayamanusia. Jakarta: Penerbit PT. RinekaCipta.

(2004). Kecerdasanemosional: Mengapa EI lebihpentingdaripada IQ. Jakarta: GramediaPustakaUtama.

(2006). Kepemimpinanberdasarkankecerdasanemosi. Jakarta: PT. GramediaPustakaUtama 
